\title{
"O MEU ESTRANHO MUNDO SECRETO": IDENTIDADE LÉSBICA E HOMOEROTISMO EM EU SOU UMA LÉSBICA, DE CASSANDRA RIOS
}

\author{
"MY STRANGE SECRET WORLD": LESBIAN IDENTITY AND \\ HOMOEROTISM IN I AM A LESBIAN, \\ BY CASSANDRA RIOS
}

\author{
Paula Laís Pombo de Morais ${ }^{1}$ \\ [https://orcid.org/0000-0003-1833-4423] \\ Flávio Pereira Camargo ${ }^{2}$ \\ [https://orcid.org/0000-0001-9116-2432] \\ DOI: 10.30612/raido.v14i35.11362
}

\begin{abstract}
RESUMO: Este trabalho tem como objetivo fazer uma leitura crítica das representaçôes da mulher lésbica no romance Eu sou uma lésbica (1980), da escritora paulistana Cassandra Rios, cujas obras foram consideradas pornográficas e censuradas durante o regime militar brasileiro. Ao acompanharmos as recordaçōes da protagonista Flávia, observamos uma série de questionamentos em torno de sua identidade e de seus desejos por outras mulheres, o que evidencia questôes relacionadas ao homoerotismo feminino, ao preconceito e à discriminaçâo da mulher lésbica em um contexto histórico-social marcadamente repressor, sobretudo em relaçăo às identidades consideradas como nâo hegemônicas. Para alcançar nossos objetivos na leitura do romance de Rios, valemonos dos conceitos teórico-críticos de George Bataille (1987), Judith Butler (2003), Tânia Navarro-Swain (2004), Adriane Piovezan (2005), Isabela Nóbrega (2015), e Anderson Guimarâes (2013), dentre outros, que nos possibilitaram uma compreensâo mais acurada sobre as representaçôes da mulher lésbica na literatura de Cassandra Rios.
\end{abstract}

Palavras-chave: Cassandra Rios. Lesbianidade. Representaçôes da mulher lésbica. Identidade. Erotismo.

ABSTRACT: This work aims to make a critical reading of the representations of the lesbian woman in the novel I am a lesbian (1980), by the Sâo Paulo writer Cassandra Rios, whose works were considered pornographic and censored during the Brazilian military regime. When we follow the memories of the protagonist Flávia, we observe a series of questions about her identity and her desires for other women, which highlights issues related to female homoeroticism, prejudice and discrimination against lesbian women

1 Graduada em Letras-Português e respectivas literaturas pela Unviersidade Federal do Sul e Sudeste do Pará. Especialista em Estudos Literários pela Universidade Federal de Goiás.

2 Professor Associado de Literatura Brasileira da Faculdade de Letras, da Universidade Federal de Goiás, com atuaçăo na Graduaçăo e no Programa de Pós-Graduaçăo em Letras e Linguística. 
in a markedly social-historical context repressive, especially in relation to identities considered as non-hegemonic. To achieve our goals in reading Rios's novel, we used the theoretical and critical concepts of George Bataille (1987), Judith Butler (2003), Tânia Navarro-Swain (2004), Adriane Piovezan (2005, Isabela Nóbrega (2015), and Anderson Guimaráes (2013), among others, that enabled us to have a more accurate understanding of the representations of lesbian women in Cassandra Rios' literature.

Keywords: Cassandra Rios. Lesbian. Representations of lesbian women. Identity. Eroticism.

\section{CONSIDERAÇÕES INICIAIS}

As mâos nos seios, a boca na boca, a sandália entre os nossos corpos, o fetiche assassino, o fetiche estuprador, o fetiche simbólico que procurava seu esconderijo, o corpo que se movia para engolir o salto, a sandália metida entre os nossos corpos, rolando na cama, tecido rasgando, gemidos e palavras soltas, sem nexo, sôfregos e dolorosos, entre lágrimas e suor, pernas cruzando, coxas ajeitando-se, borboletas de asas negras estranhando-se numa dança frenética e sensual, numa fantasia que fez uma criança virar monstro e uma mulher se sentir anjo (RIOS, 1980, p.131).

Sob uma temática vista como transgressora e pornográfica, Cassandra Rios, pseudônimo de Odete Rios, é considerada a pioneira da literatura lésbica no Brasil. A escritora, que foi perseguida e que teve a maior parte de suas obras impedidas de circular, no período em que vigorava a Ditadura Militar, ${ }^{3}$ é um dos nomes que foram silenciados no século XX.

Sobre as obras de Cassandra Rios, a maioria traz mulheres lésbicas como personagens principais; muitas, marginalizadas e culpadas por amarem e, sobretudo, desejarem outras mulheres. A autora também produziu obras em que personagens compreendiam a homossexualidade como uma característica de sua natureza, que deveria ser assumida socialmente; é o que acontece, por exemplo, no romance Nicoleta Ninfeta (1973), no qual a protagonista Adriana acredita que "as lésbicas deveriam se assumir enquanto tal" (DIAS, 2012, p. 59).

A escritora paulistana, que morreu em 2002, era conhecida como a "Safo de Perdizes" pela recorrência da temática lésbica. Por causa disso, Cassandra Rios teve sua vida financeira comprometida. Contudo, vale ressaltar que ela foi uma das poucas escritoras que conseguiu sobreviver de direitos autorais na década de 1980.

Por isso, retomar a obra de Cassandra Rios é, também, falar de uma mulher que certamente estava à frente de seu tempo e que conseguiu resistir, através de um

3 O Regime Militar foi o período da política brasileira em que militares conduziram o país. Essa época ficou marcada na história do Brasil através da prática de vários Atos Institucionais que colocavam em prática a censura, a perseguiçáo política, a supressâo de direitos constitucionais, a falta total de democracia e a repressáo àqueles que eram contrários ao regime militar. A Ditadura militar no Brasil teve seu início com o golpe militar de 31 de março de 1964, resultando no afastamento do Presidente da República, Joáo Goulart, e tomando o poder o Marechal Castelo Branco. Este golpe de estado, caracterizado por personagens afinados como uma revoluçấo instituiu no país uma ditadura militar, que durou até a eleiçáo de Tancredo Neves em 1985. Os militares na época justificaram o golpe, sob a alegaçáo de que havia uma ameaça comunista no país. FONTE: https://www.sohistoria.com.br/ef2/ditadura/ (Acesso em 26/04/2020). 
posicionamento político e social, indo contra a heterossexualidade compulsória conceito criado por Judith Butler (2003, p.167-168) para questionar o discurso que compreende toda a sociedade como heterossexual. Ou melhor, a escritora mostrou possíveis identidades femininas ligadas ao homoerotismo, ao prazer e ao amor entre mulheres.

Assim, a obra selecionada para este trabalho foi Eu sou uma lésbica, publicada em 1980, que tem como protagonista Flávia: jovem, de classe média, branca e lésbica. A história é narrada em primeira pessoa, na qual a narradora-personagem, dotada de toda onisciência, faz recordaçôes de suas atitudes desde a infância até o momento atual, com análises constantes, com o objetivo de afirmar sua identidade enquanto lésbica.

Ao longo da narrativa, Flávia vai questionando estigmas que acompanham a mulher lésbica na sociedade, e parece querer reforçar para si que năo se enquadra nas práticas discursivas construídas ao longo do tempo. Por isso, em vários momentos, seja por meio de açôes ou pensamentos, ela nos leva à compreensâo de que a sua sexualidade năo compromete, por exemplo, a sua feminilidade. Além disso, a obra aborda os preconceitos e a discriminaçấo a respeito da homossexualidade na década de 1980, período em que os homossexuais - masculinos e femininos - eram concebidos como portadores de doença mental.

[...] até 1973 o comportamento homossexual foi considerado doença, quando a Associaçăo Americana de Psiquiatria (AAP) suprimiu a preferência sexual por indivíduos do mesmo sexo do rol de doenças mentais. A palavra perdeu o sufixo "ismo", que significa doença, e adotou o "dade", que significa modo de ser. E em 1993, foi a vez da Organizaçăo Mundial da Saúde (OMS) retirar a homossexualidade de sua lista de patologia (AMORIM, 2014, p. 13).

Desse modo, é importante destacar que embora vivamos num período (histórico), teoricamente evoluído, falar sobre a sexualidade humana ainda é marcada pelo tabu. Quando o tema é a homossexualidade, a tarefa é ainda mais complexa. Isso ocorre porque, no cerne dessa discussăo, temos dois elementos considerados, pela sociedade, como opostos, porém complementares: o homem e a mulher heterossexuais.

Nesse sentido, Sara Salih (2015, p. 181), diz que é imposto que o desejo homossexual seja reprimido e repudiado para que a identidade heterossexual seja formada, o que pode levar héteros e/ou homossexuais a viverem uma espécie de melancolia. Segundo a autora, desejar um sujeito do mesmo sexo quando adulto significa fazer o gênero "entrar em pânico" (SALIH, 2015, p.183), visto que ameaça uma identidade aparentemente estável, fazendo a homossexualidade ser demonizada.

Portanto, antes de seguirmos para a análise, é válido trazer à tona o seguinte questionamento proposto por Cassandra Rios: “Em que situaçăo uma homossexual deve ser rejeitada, compreendida ou aceita? Quando engana o homem com as suas dissimulaçôes ou quando enfrenta a sociedade abertamente?" (1980, p.132).

Embalada pelas indagaçôes de Cassandra Rios acerca da identidade, do erotismo, da "aceitaçăo" da mulher lésbica é que justifico a escolha do tema, que se dá em decorrência de um apagamento, de um silenciamento da obra da escritora devido às temáticas abordadas, as quais evidenciam sexualidades tidas como divergentes, sendo esse o principal motivo de Cassandra Rios ter sido rotulada como a escritora mais proibida do Brasil. 
A discussáo em torno das relaçôes entre os gêneros e, em especial, acerca da identidade da mulher lésbica, com uma linguagem mais direta e acessível, por meio da qual fala sem censura sobre sexo e prazer entre mulheres, fez a literatura de Cassandra Rios ser considerada imprópria e até combatida pelo governo. Isso porque a escritora paulistana ousou desafiar o modelo heteronormativo quando, em seus romances, trouxe possibilidades de desejo e amor entre duas mulheres.

Daí a necessidade de resgatar sua obra e colocar em destaque a representaçâo da mulher lésbica e suas relaçōes homoeróticas, seus desejos, seus afetos, além dos preconceitos que ainda parecem estar enraizados na sociedade. Porém, devemos dizer que os motivos náo sáo apenas pessoais, mas sociais, políticos e acadêmicos, uma vez que por meio da literatura também podemos resistir e lutar contra discursos que estabelecem a heterossexualidade como absoluta.

É importante ressaltar que para nós, lésbicas e homossexuais, a resistência é crucial para que nâo sejamos anulados, visto que a sociedade heterossexual (historicamente) procura invalidar constantemente a homossexualidade. Segundo Monique Wittig (2005), o "pensamento hetero" é opressor ao estabelecer como obrigatória a relaçăo entre "homem" e "mulher", concebendo como impossível outras vivências sexuais.

Além disso, conforme aponta Wittig (2005), a sociedade heterossexual se firma na necessidade de apontar, depreciar, dominar aquele que considera diferente, ou seja, o outro. Como todos sabemos, ou deveríamos saber, as minorias sâo colocadas em posiçăo inferior, de dominado. E embora lésbicas, gays, bissexuais, sempre tivéssemos existido, fomos invisibilizados. Por isso, a relevância de fazermos esse estudo, tendo em vista que é uma maneira de nos dar voz e nos fortalecer política e socialmente.

Assim, o objetivo desse trabalho é fazer um breve levantamento da recepçăo crítica da obra de Cassandra Rios, especialmente sobre este romance, com a finalidade de abordar a identidade lésbica e o homoerotismo feminino a partir das discussōes de autores como George Bataille (1987), Judith Butler (2003), Tânia Navarro-Swain (2004), Adriane Piovezan (2005), Guacira Louro (2004), Isabela Nóbrega (2015), Anderson Guimarâes (2013), dentre outros que discutem sobre as representaçôes de mulheres lésbicas.

\section{CASSANDRA RIOS: UMA ESCRITORA À FRENTE DE SEU TEMPO}

A Mitologia Grega conta que Cassandra, uma princesa, filha de Príamo e Hécuba de Tróia, se tornou profetiza quando o deus Apolo ensinou-lhe a arte das premoniçôes. No entanto, ao se recusar a manter relaçôes sexuais com ele, Cassandra foi amaldiçoada, sendo condenada à incredulidade quanto às suas profecias. ${ }^{4}$

Inspirada pela mitologia, Odete Rios Perez Gonzáles Hernândez Arellano adotou o pseudônimo de Cassandra Rios para dar vida à escritora que foi perseguida e considerada pornográfica, tendo muitas de suas obras censuradas por abordar o homoerotismo feminino.

Mito de Cassandra. FONTE: https://cultura.culturamix.com/curiosidades/cassandra-mitologia. (Acesso em 14/01/2020). 
Segundo Kyara Maria de Almeida Vieira (2014), a autora nasceu em Sáo Paulo, em 03 de outubro 1932, no Bairro de Perdizes, e desde muito jovem começou a participar de concursos em jornais, época em que já assinava como Cassandra Rios, aos 13 anos de idade. A ideia do pseudônimo foi uma espécie de escolha (in) voluntária, pois em uma entrevista concedida a Fernando Luna, da Revista TPM, em 2001, ela teria dito que ouvia uma voz chamando-a por esse nome: "Cassandra, Cassandra" (LUNA, 2001, p.8 apud PIOVEZAN, 2005, p. 21).

Cassandra Rios era lésbica e a maior parte de suas obras possui temática lésbica. De acordo com Adriane Piovezan (2005), esses aspectos fizeram com que se imaginasse que a autora retratava, através dos romances, somente suas experiências pessoais. Contudo, a própria Cassandra Rios chegou a se ofender, pois entendia que isso feria sua "capacidade criativa" como ficcionista (RIOS, 1977, p.103 apud PIOVEZAN, 2005, p.20).

Aos 16 anos, a autora publicou seu primeiro livro, A Volúpia do Pecado (1948), com ajuda financeira da máe, Damiana Rios: "uma espanhola religiosa, que emprestou o dinheiro para o projeto da filha com a condiçăo de jamais ler sequer uma linha de seus livros" (PIOVEZAN, 2005, p.22).

A obra narra a paixâo entre duas moças, Lyeth e Irez, descritas como modelos de feminilidade e que vivem um relacionamento amoroso, descartando assim qualquer característica patológica, segundo afirma Piovezan (2005). É interessante evidenciar a contradiçâo exposta por Cassandra Rios entre o título da obra e a caracterizaçáo das personagens, as quais naturalizam o amor que sentem uma pela outra e, consequentemente, sua sexualidade, indo contra a ideia de pecado atribuída às relaçóes lésbicas e homossexuais.

Isso porque, a autora traz, na narrativa, o prazer provocado e sentido entre corpos femininos sob uma perspectiva que contradiz o discurso enraizado socialmente (cristâo e heterossexual), o qual prega a homossexualidade como um pecado digno de puniçấo. Quando se trata de mulheres, é ainda mais complexo, visto que o corpo feminino, segundo a concepçăo social, nasceu para ser educado e doméstico. Simone de Beavoir (1967, p. 112) diz que

A civilizaçăo patriarcal votou a mulher à castidade; reconhece-se mais ou menos abertamente ao homem o direito a satisfazer seus desejos sexuais ao passo que a mulher é confinada no casamento: para ela o ato carnal, em nâo sendo santificado pelo código, pelo sacramento, é falta, queda, derrota, fraqueza; ela tem o dever de defender sua virtude, sua honra; se "cede", se "cai", suscita o desprezo; ao passo que até na censura que se inflige ao seu vencedor há admiraçăo.

Isto é, o prazer erótico para a mulher era invisibilizado; se esse prazer se dava entre duas mulheres, era inconcebível. Podemos dizer que essa é uma qualidade da escrita de Cassandra Rios, uma vez que ela retoma em suas histórias a homossexualidade e o erotismo feminino como algo possível e natural entre duas mulheres, conforme vemos abaixo:

Em A volúpia do pecado o enfoque é outro. Trata-se de uma história de amor tâo romântica como uma história de amor heterossexual poderia ser. No livro, 
Cassandra narra a história de um amor homossexual entre mulheres como possível e natural, e a representaçáo do sujeito lesbiano como qualquer mulher, de qualquer grupo social. (PIOVEZAN, 2005, p. 49).

Isto é, ela rompe com a ideia de que a lesbianidade, por exemplo, é uma doença que precisa ser tratada. Em sua narrativa, a autora procura descontruir os estereótipos acerca da homossexualidade feminina, por este motivo ela é considerada a precursora da literatura lésbica no Brasil, ao trazer à tona um tema apontado como marginal e transgressor: o homoerotismo entre mulheres.

É válido destacar que entre as décadas de 1948 e 1980, período em que a escritora esteve mais ativa, a ideia de sexo imposto às mulheres năo estava vinculada ao prazer, aliás, era como uma obrigaçâo para atender às demandas do casamento. Por isso, o que Cassandra Rios faz por meio de suas obras é "rasurar" os papéis atribuídos à mulher dentro da sociedade patriarcal.

Isso porque, na concepçâo machista, as mulheres sâo destinadas aos cuidados do lar, do marido e dos filhos, devido à crença de superioridade masculina. De acordo com Castańeda (2006, p. 16), o machismo engloba "toda uma forma de vida baseada nele", ou seja, está relacionado também ao comportamento social, no qual o homem percebe a mulher como sua propriedade, sendo aquela que viverá para lhe servir.

Assim, quando Cassandra Rios escreve sobre outras possibilidades, em especial no que se refere à sexualidade feminina, tem suas obras censuradas, visto que coloca a mulher como dona de si, de suas vontades e desejos, o que năo foi bem visto socialmente já que, nos romances da escritora, o homem năo representa a figura desejada pelo sexo oposto.

No que diz respeito à censura, é importante ressaltarmos que esta interferiu em todas as possíveis formas de expressăo, assim como em relaçăo às obras literárias. Para "atender" esse departamento, Getúlio Vargas criou, por intermédio do Decreto n ${ }^{0}$ 93, de 21 de dezembro de 1937, o Instituto Nacional do Livro (INL), o qual apresenta as seguintes competências:

Art. $2^{\circ}$ Competirá ao Instituto Nacional do Livro;

a) organizar e publicar a Enciclopédia Brasileira e o Dicionário da Língua Nacional, revendo-lhes as sucessivas ediçôes;

b) editar toda sorte de obras raras ou preciosas, que sejam de grande interesse para a cultura nacional;

c) promover as medidas necessárias para aumentar, melhorar e baratear a ediçăo de livros no país bem como para facilitar a importaçăo de livros estrangeiros;

d) incentivar a organizaçăo e auxiliar a manutençăo de bibliotecas públicas em todo o território nacional. (BRASIL, 1937, art. $\left.2^{\circ}\right)$.

É, portanto, através do INL que o governo passa a controlar as publicaçōes brasileiras, julgando o que seria "apropriado" ou náo para o público. Conforme Garbin (2013), o Instituto foi usado como suporte para justificar até açóes culturais realizadas pelos militares.

Nesse sentido, a maneira como o governo agia se configurava como opressora da liberdade de expressâo; a censura, dessa forma, funcionava como uma ferramenta 
controladora, de modo a definir o que chegaria às măos da massa popular. Desse modo, a fim de garantir a censura prévia para livros, foi criado o Decreto-lei $n^{\circ} 1.077$, de 26 de Janeiro de 1970.

Esse regulamento, já em seu artigo $1^{\circ}$, estabelece que "năo serăo toleradas as publicaçóes e exteriorizaçóes contrárias à moral e aos bons costumes quaisquer que sejam os meios de comunicaçấo" (BRASIL, 1970). Cabe ressaltar que, obviamente, a moral e os bons costumes aos quais o decreto se refere dizem respeito ao padrăo cristăo e heteronormativo.

Modelos nos quais a literatura de Cassandra Rios năo se encaixa, visto que suas obras destacam o protagonismo lésbico, explorando, através das personagens, o tabu do gozo feminino, da satisfaçăo sexual sem a presença do homem. Isabela Nóbrega (2015) afirma que os romances de Cassandra Rios contribuíram para a visibilidade dos homossexuais, resultando num grande número de venda de seus livros, mas também sendo motivo de polêmica e repressâo, conforme lemos na citaçăo a seguir:

\begin{abstract}
Motivada por essas questôes e apoiada na legislaçăo do período, a censura condenou sua obra e constantemente fez apreensóes dos seus livros em bancas de jornais e livrarias, mas em contrapartida a própria repressăo possibilitou um maior número de vendagem para a autora, que em algumas de suas capas explorava essa condiçăo e apresentava-se como "a autora mais proibida" ou "mais um livro proibido" (NÓBREGA, 2015, p.96, grifos da autora).
\end{abstract}

Ainda de acordo com Nóbrega (2015), a escritora foi intitulada como pornográfica pelo governo, sendo alvo de vários processos criminais que levaram à censura de obras como Copacabana Posto 6 (1961), Ariella, a paranóica (1969), Veneno (1968), Marcella (1975), Macária (1974), As Traças (2002), Nicoleta Ninfeta (1973), A Borboleta Branca (1980), A Breve Estória de Fábia (1964), A Serpente e a Flor (1972), A Volúpia do Pecado (1948), entre outras.

Assim, 36 livros de Cassandra Rios foram censurados por serem considerados imorais, perigosos e obscenos; simplesmente por terem como tema central relaçóes amorosas e sexuais, em especial, entre mulheres. Esta censura em relaçăo à obra de Cassandra Rios, implica que, para os censores, ou melhor, para o governo, os livros da escritora colaboravam para a degradaçăo da família, uma vez que:

A sexualidade e a pornografia no Brasil das décadas de 1960 e 1970 eram enxergadas pela sociedade e seus mecanismos de censura - fossem eles autoridades religiosas, civis ou políticas - respectivamente, como forma de ordenamento e degradaçấo social. Tinha-se o sexo e a heterossexualidade como normas para a reproduçáo dos padróes morais e cristăos. Sendo assim, a família e a propriedade estariam resguardadas dos perigos da deterioraçâo. (NÓBREGA, 2015, p. 88).

Nesse sentido, as obras de Cassandra Rios assumem caráter subversivo, pois enquanto a sociedade discrimina homossexuais como seres doentes e marginais, a autora ignora o preconceito para afirmar em seus enredos "o ser lésbica ou gay" como algo intrínseco à natureza do ser humano.

Além disso, seus livros trazem uma denúncia de comportamentos homofóbicos comumente vistos na sociedade, como a violência sofrida por homossexuais. Em Eu sou uma lésbica (1980), Cassandra Rios narra a agressăo cometida contra uma lésbica 
em uma festa de carnaval. Por ser masculinizada, os seguranças impedem sua entrada, o que provoca a confusão e as pauladas de cassetete desferidas contra a "machona".

Antes disso, a obra deixa explícita a discriminaçăo quando um dos homens responsáveis pelo baile diz: "- Náo deixe entrar, devolva os ingressos, devolva o dinheiro; paraíbas aqui năo entram" (RIOS, 1980, p.96, grifo nosso). Ou seja, é evidente que o homossexual, masculino ou feminino, nesta e em tantas outras narrativas é marginalizado. Neste caso, em específico, há uma representaçăo da lésbica masculinizada, pois o vocábulo "paraíba" era e ainda é utilizado para se referir de forma pejorativa às mulheres lésbicas cuja performance de gênero seja mais masculina do que feminina, o que nos remete a um discurso homofóbico. Para Daniel Borillo,

Confinado no papel do marginal ou excêntrico, o homossexual é apontado pela norma social como bizarro, estranho ou extravagante [...]. À semelhança do negro, do judeu ou de qualquer estrangeiro, o homossexual é sempre o outro, o diferente, aquele com quem é impensável qualquer identificaçâo. (BORILLO, 2010, pp.13-14).

É justamente por causa da ideia de que o diferente representa o desigual que o homossexual é colocado em posiçâo inferior, pois é como se sua sexualidade ferisse a "normalidade"; sendo essa ideia estabelecida culturalmente, o homossexual seria visto como uma figura avessa aos princípios morais.

Dessa maneira, a escrita de Cassandra Rios vem para desestabilizar os discursos construídos acerca da homossexualidade, já que a autora coloca "héteros e homos" em situaçâo equânime ao "desmistificar" a sexualidade humana, ao expor, sobretudo, os desejos, a atraçâo comum a todo e qualquer indivíduo independente do sexo com o qual se relaciona.

Contudo, na literatura de Cassandra Rios há uma problemática bem mais evidente: a mulher lésbica, que sofre duplamente, ora pelo gênero, ora pela orientaçăo sexual. De acordo com Ana Gabriela Pio Pereira (2013), muito provavelmente a invisibilidade que acomete esse público foi um dos motivos para a afirmaçấo da escritora na produçâo literária, pois:

Essas narrativas sobre mulheres que se envolvem afetiva e sexualmente com outras mulheres inserem, no cenário literário nacional, personagens até entăo vistas de forma estereotipada, na condiçăo de protagonista; condiçăo esta que lhes permite investir na constituiçăo de narrativas de si. (PEREIRA, 2013, p.19).

Significa dizer que nas obras de Cassandra Rios as protagonistas lésbicas têm a oportunidade/possibilidade de se descreverem, de performarem sua sexualidade de uma forma mais subjetiva, rompendo com os estereótipos e contornando a identidade lésbica como algo mais flexível, sem precisar pertencer a um padrăo pré-estabelecido.

Pereira (2013, p. 19) dá como exemplo a obra As Traças (1970), de Cassandra Rios, que tem como personagem principal a adolescente Andréa, de 17 anos, que se "percebe" lésbica após se apaixonar por uma de suas professoras - Berenice, uma mulher mais velha.

Todavia, Pereira (2013) afirma que, após se questionar, a jovem entende sua homossexualidade como algo que sempre existiu, porém de forma dormente. “Para ela, as 
sensaçóes que experimentava eram as evidências de que estaria acontecendo algo que "a vida inteira pressentiu" e que, de certa forma, "temia aclarar-se"'" (PEREIRA, 2013, p. 19, grifos da autora).

O medo de Andréa em se reconhecer homossexual era, em partes, pelo desconhecimento sobre o assunto, visto que era membro de uma família tradicional, embutida de valores heterossexuais, sendo, portanto, inexperiente. Assim, empenhou-se em pesquisar tudo o que se poderia encontrar sobre a lesbianidade na década de 1970 período em que a medicina ainda concebia as relaçôes homossexuais como patológicas. (PEREIRA, 2013, p. 21).

Conforme Pereira (2013, p.22), quando Andréa deixa de pesquisar o conceito de lésbica e passa a ler "como os homossexuais foram inscritos no contexto histórico-cultural do Ocidente", a adolescente compreende que homossexuais săo, na verdade, descritos como sujeitos resultantes de constructos sociais e práticas discursivas.

Podemos dizer que Cassandra Rios traz, mesmo sob censura, várias maneiras de se discutir o homoerotismo feminino, por apresentar possibilidades de existência aos sujeitos homossexuais; e, enfim, de resistir por meio de sua escrita.

\section{IDENTIDADE E HOMOEROTISMO EM EU SOU UMA LÉSBICA, DE CASSANDRA RIOS}

\footnotetext{
Mudas as duas no meio do quarto. Ela, linda na sua camisola longa de tecido transparente, os seios sempre emoldurados pelo decote, soltinho lá dentro da névoa negra que a envolvia suavemente, embelezando seu corpo. Meus olhos, os mesmos olhos, agora num olhar grande e faminto, colhiam-na toda. (RIOS, 1980, pp.129-130)
}

Simone Brandāo (2018, p. 137) diz que apesar de a existência da lesbianidade ser antiga, estudos acerca do assunto só começaram a aparecer a partir da década de 1970 , através dos quais a identidade da mulher lésbica passou a ser evidenciada. Contudo, a autora destaca que no que se refere à homossexualidade, os gays, de certa forma, tiveram mais "atençầo", sendo as lésbicas invisibilizadas.

Ainda conforme Brandăo (2018, p. 137), essa invisibilidade perpassa o campo acadêmico, o qual nâo possui muitas produçóes de trabalhos com essa temática, deixando de lado, principalmente, "as especificidades do universo lésbico". Ela destaca que ao abordar a lesbianidade é preciso considerar as singularidades, subjetividades das identidades lésbicas.

Para Tânia Navarro-Swain (2004), a sexualidade lésbica sofre de alguns mitos, tal qual a associaçâo dessa identidade a uma mulher ninfomaníaca ou, entâo, aquela cujo desejo sexual é quase inexistente. Podemos dizer que essas distorçôes săo uma das formas de a sociedade tentar estabelecer domínio sobre corpos e sexualidades que nâo seguem os padrōes pré-estabelecidos. Dessa maneira, é possível afirmar que, durante muito tempo, enquanto eram demonizadas, as lésbicas também eram alvo de classificaçōes inglórias. Todavia, de acordo com Navarro-Swain, nâo existe uma única identidade lésbica:

Năo há UMA identidade lesbiana, pois năo há um modelo a ser seguido, năo há uma receita, nâo há mistérios; pressente-se uma busca e um conhecimento do 
próprio corpo que é utilizado no prazer de outrem e de si mesmo. [...] O "mistério" da sexualidade lésbica permanece enquanto tal na medida que náo existe, um padrăo de comportamento, uma postura unitária, uma "maneira de fazer" imposta a todas, uma "posiçăo" clássica obrigatória. (NAVARRO-SWAIN, 2004, p.86, grifos da autora).

Assim, tanto as práticas sexuais como o comportamento lésbico săo elementos fluidos e flexíveis, pois "a seduçâo, o contato, o namoro, o toque, o cheiro sâo desdobramentos da emoçâo. Humana emoçâo, troca de humores, erótica reinventada"(NAVARRO-SWAIN, 2004, p.86).

Judith Butler (2003, pp.24-25), um dos principais nomes da teoria queer, problematiza, dentre outras questóes, justamente a rigidez de uma matriz heteronormativa quanto à identidade, gênero, sexo e sexualidade. Ela questiona a produçâo social e cultural desses conceitos, principalmente no que se refere ao ser "mulher/homem", ao contestar o caráter imutável do sexo e do gênero.

Ao retomar Monique Wittig, Butler (2003, p.164) diz que a lésbica transcende aquilo que é definido como binário, uma vez que năo se encaixa na definiçăo de mulher, pois o termo mulher existe para contrapor o conceito de homem, no plano heterossexual:

E, demais, a lésbica năo tem sexo: ela está além das categorias do sexo. Por meio da recusa lésbica dessas categorias, a lésbica (e os pronomes săo aqui problemáticos) denuncia a constituiçăo cultural contingente dessas categorias e a pressuposiçăo tácita mas permanente da matriz heterossexual. (BUTLER, 2003, pp.24-25).

Ela compreende que a identidade lésbica seria um terceiro gênero que se opóe à "heterossexualidade compulsória" (BUTLER, 2003, p.165). Isto é, que pressupooe toda a sociedade como heterossexual, na qual o sujeito que foge à norma năo possui lugar de fala (BUTLER, 2003, p. 168), resultando na inferiorizaçấo dos homossexuais pelo olhar/discurso dos heterossexuais.

Nesse sentido, discutir sobre a identidade lésbica é falar sobre possibilidades da sexualidade feminina, já que năo existe um padrâo, muito embora haja um discurso que procura associar mulheres lésbicas, por exemplo, somente àquelas masculinizadas, chamadas pejorativamente de "caminhoneiras".

É válido ressaltarmos que as práticas discursivas em torno da lesbianidade apenas reforçam seu caráter fantasioso, já que compreender-se lésbica está para além da ideia caricatural masculina. Ser lésbica em nada tem a ver com a anulaçâo da feminilidade ou da desvalorizaçăo da mulher.

Em Eu sou uma lésbica (1980), de Cassandra Rios, a protagonista Flávia se entende lésbica desde muito pequena - aos 7 anos de idade - quando se vê atraída por uma vizinha, dona Kênia, amiga de sua măe. A mulher por quem se apaixonara era casada, tinha mais de vinte anos, heterossexual, um exemplo de feminilidade: "As sandálias de tirinhas coloridas, o salto muito fino e alto, a cor da saia e seu perfume me entorpeciam" (RIOS, 1980, p.09).

Conforme vai relembrando sua história, desde esse primeiro amor, Flávia reforça que ser uma mulher atraída pelo mesmo sexo sempre fez parte de sua natureza. Ela, a mais nova de três filhos, conta que nunca teve dúvidas quanto a sua sexualidade, e, ao contrário de muitas, năo se sentia culpada por ser lésbica: "O beijo no escuro, durante a brincadeira de gatinho, fora um impulso instintivo irreprimível que definira aquilo que eu era e que nunca temera reconhecer - lésbica" (RIOS, 1980, p.51). 
Assim, enquanto vai compreendendo que sua orientaçâo sexual se configurava como algo natural e parte de sua identidade, a personagem principal também descontrói o estigma de que a homossexualidade está relacionada a alguma doença; ela percebe que seu sofrimento está voltado, na verdade, para o amor irrealizado:

Sinto-me mentalmente sadia, mesmo quando sofro, quando a depressăo me dá ganas de suicídio e me debato, rezo, blasfemo e estrebucho como um frango ao ser degolado - assim me sinto quando a dor do amor faz sangrar a alma e queimar a carne. [...] $\mathrm{O}$ que eu quero afirmar é que em mim tudo é natural, consciente, vivo, espontâneo. (RIOS, 1980, p.28).

Flávia, entăo, compreende que jamais irá se interessar por homens como se interessa pelas mulheres. Dessa maneira, a consciência que a protagonista tem sobre si e sobre sua sexualidade faz com que ela vá modelando sua personalidade e performance como uma lésbica. A partir daí a protagonista traz uma série de questionamentos em torno da noçáo de feminilidade como parte da identidade da mulher lésbica.

Isto é, Flávia se reconhecia enquanto uma lésbica genuína: uma mulher que se apaixona por outras mulheres, que se vê tendo relacionamentos íntimos apenas com pessoas do mesmo sexo, e que sabia dissociar, por exemplo, a orientaçăo sexual da identidade de gênero. Para ela, sua homossexualidade nâo a obrigava a assumir uma postura masculina: "Eu era mulher, essencialmente feminina, apenas gostava de mulher, só isso." (RIOS, 1980, p. 56).

Mesmo tendo definido sua identidade internamente, Flavia năo conseguia se expressar para o mundo como uma mulher lésbica por medo dos julgamentos sociais. Ela acreditava que a sua feminilidade, de certa maneira, contribuía para isso, visto que as lésbicas "assumidas", na década de 1980, eram aquelas que esteticamente se assemelhavam aos homens fisicamente ou de modo performático.

Vale destacarmos que, conforme a personagem relata na narrativa, o momento em que vai adquirindo mais esclarecimentos a respeito de sua sexualidade é também um período histórico em que os homossexuais eram extremamente marginalizados. Com isso, Flávia se percebe num conflito estabelecido por dois motivos: o primeiro pela crítica à ideia de que toda lésbica que saía do "armário" deveria ser masculinizada; e o segundo, por năo saber se posicionar política e socialmente como uma mulher feminina e lésbica.

Todavia, a protagonista acaba, mesmo sem querer, deixando explícito seu preconceito contra lésbicas que năo săo femininas, criticando esse tipo de performance. Flávia se refere às lésbicas masculinizadas como "machonas", deixando clara sua repulsa, reforçando, assim, o preconceito e a discriminaçâo contra identidades consideradas transgressoras.

O posicionamento da protagonista nos faz refletir sobre a contradiçăo entre o desejo de Flávia em ser vista apenas como uma mulher que deseja outras mulheres, e a perpetuaçâo do preconceito mediante seu comportamento discriminatório para com lésbicas com performance de gênero masculina; como se a identidade lésbica precisasse de uma padronizaçăo para ser "aceita" na sociedade.

Navarro-Swain (2004, p. 91, grifos da autora) afirma que "o lesbianismo năo pode constituir uma identidade, já que esta denominaçăo năo é senăo um conjunto de questōes, de práticas diluídas no questionamento das categorias mulher e gênero". Ou 
seja, discutir a identidade lésbica é questionar um "contra-imaginário domesticado" e evidenciar as singularidades ligadas às identidades lésbicas.

Eduardo Leal Cunha (2009 apud GUIMARĂES, 2013, p.116) afirma que a formaçăo identitária é, sobretudo, um processo que envolve tanto a consciência quanto a autoconsciência. $O$ autor aponta que identidade é um conceito múltiplo, que dá vazâo a várias possibilidades, por isso, ele destaca que essa construçăo é um diálogo estabelecido entre o indivíduo e a sociedade. Isso significa dizer que

É preciso mais do que a simples consciência do papel social de cada indivíduo no processo de formaçâo identitária, é necessário uma autoconsciência, para que as praxes do grupo sejam integradas à narrativa da identidade do indivíduo, pois a consciência está ligada ao campo da experiência do dia-a-dia, enquanto a autoconsciência refere-se ao reconhecimento do si mesmo como um indivíduo que tem sua própria subjetividade (CUNHA, 2009 apud GUIMARÂES, 2013, p.116).

Por isso, ao falarmos de identidade, também, tratamos de posicionamento político, que precisa ser afirmado socialmente. No caso da protagonista Flávia, a feminilidade como parte da sua identidade lésbica acaba por se anular dentro do padrăo heteronormativo, tendo em vista o receio em falar abertamente sobre sua orientaçăo sexual.

Nesse sentido, Guimarâes (2013) reforça a importância de as lésbicas admitirem sua identidade, visto que esta é uma maneira de resistir e lutar contra o preconceito, bem como desfazer os estereótipos. Ele fala, ainda, da necessidade de transformar essa identidade, tantas vezes estigmatizada, em uma ferramenta que "mostre suas diversas maneiras de existir nos mais diferentes espaços e denunciar as discriminaçōes" (GUIMARĂES, 2013, p. 119).

Partindo dessa compreensăo, cabe observarmos outra questăo bastante presente nesta obra de Cassandra Rios: o homoerotismo; o desejo ardente e quase incontrolável da protagonista Flávia. Durante a narrativa em primeira pessoa, a jovem recorda que desde criança já se sentia entorpecida pelo sentimento de excitaçâo causado por sua vizinha, Kênia.

Engraçado que eu nunca tenha apelado para a masturbaçăo (sei que há crianças até de dois anos que, flexionando o corpo, por um movimento do tronco, quando sentadas, masturbam-se). Durante os sonhos, porém, eu chegava a sentir uma sensaçăo gostosa nos órgăos sexuais, alcançava um certo prazer, e a simples visáo de dona Kênia era o suficiente para me transtornar (RIOS, 1980, p.08).

Apesar de muito pequena, a personagem já tinha aflorado o desejo sexual; um desejo que se apresentava como aquele que seria motivado por uma pessoa do mesmo sexo que o dela. E embora as lembranças do erotismo precoce nos assustem enquanto leitores, isso nâo chega a ser uma anormalidade, muito pelo contrário é natural ao ser humano.

A protagonista Flávia, ainda na infância, mesmo năo tendo total consciência de sua sexualidade, já compreendia que o sentimento erótico que nutria pela amiga de sua máe poderia ser considerado como transgressor. Instintivamente, a personagem procurava esconder a perturbaçâo interna que Kênia lhe causava. Vejamos:

Eu me retraía porque sabia da intensidade do meu sentimento. De algum modo, eu entendia que náo podia demonstrar o que sentia, o que se passava comigo; por isso cada vez mais eu me transformava numa criança arredia, intimista, muda, indiferente ao que normalmente interessa as crianças. (RIOS, 1980, p.07). 
Por acreditar que o desejo que ela sente por outra mulher seja transgressor é que Flávia crê que este deve ser contido ou "esquecido". Entretanto, o esforço de evitar esse sentimento é falho. Georges Bataille (1987), a partir de um exemplo acerca da violência, explica como se daria o mecanismo da transgressăo:

O homem quis, acreditou, dominar a natureza, opondo-lhe geralmente a recusa do interdito. Limitando nele mesmo o movimento da violência, ele pensou limitá-lo ao mesmo tempo na ordem real. Mas se ele percebesse a ineficácia da barreira que quis opor à violência, os limites que ele mesmo pretendera observar pessoalmente perdiam o sentido que tinham tido para ele: seus impulsos contidos se soltavam, desde entăo ele matava livremente, deixava de moderar sua exuberância sexual e náo temia mais fazer em público e desenfreadamente o que só até entấo fazia de forma discreta. Enquanto o corpo do rei era o campo de uma decomposiçăo agressiva, a sociedade inteira estava sob o poder da violência. Uma barreira impotente para proteger a vida do rei da virulência da morte năo poderia também se opor eficazmente aos excessos que ameaçam a ordem social. (BATAILLE, 1987, p.44).

Com isso, o autor chega à conclusăo de que talvez o desejo secreto, escondido, o "transgressor", năo possa ser discreto por tanto tempo, em razăo da impulsividade de sua própria natureza. Mais adiante, em sua obra, Bataille (1987) vai dizer que o erotismo leva ao caminho da solidáo.

Isso acontece justamente porque, quando se trata do desejo erótico, esse anseio acaba se configurando como clandestino, como o objeto que năo pode ser público, de modo que "a experiência erótica se situa fora da vida ordinária" (BATAILLE, 1987, p.163). Significa dizer, portanto, que o erotismo faz parte dos interditos existentes na sociedade.

E é nesse caminho de desejo e solidăo que a protagonista do romance se encontra, tendo em vista que durante a infância, por razóes óbvias, năo pode expressar seus sentimentos sexuais por Kênia; e na fase adulta, devido a vizinha ter se mudado para outro país com o marido, Flávia tem apenas as lembranças e um lado do salto de tirinhas que ficou para trás.

A ausência física da amada é preenchida pelas memórias e pelo sapato guardado há mais de dez anos pela personagem. O objeto que pertencia à Kênia exerce um poder erótico e de certo modo fetichista em Flávia: "o demônio do desejo em mim, passos pisando macio, as sandálias prometendo orgasmos, o êxtase espantando os fantasmas da alma" (RIOS, 1980, p.63).

É nesse momento que a protagonista rompe o próprio hímen com o salto da sandália de dona Kênia. O desejo de Flávia é tăo severo que a leva a deflorar a si própria, transformando a ausência e a solidăo em tesâo, suspiros e em uma tensăo violadora, conforme vemos no excerto que segue:

Úmida de suor, molhada de tesăo, de vontade. Era Kênia quem estava ali. Năo era a minha măo que segurava a sandália, era o pé de Kênia que a calçava e vinha, e chegava, encostava, afagava e friccionava o que havia de mais alta tensăo entre as repartidas carnes no fim das coxas [...] O salto encapuzado, vestido de dedo de luva de borracha, lubrificado pela minha própria saliva, ficando lento, com cuidado, abrindo caminho, forçando sob a pressấo das minhas mâos, que năo mais vacilavam - nada as deteria - a dor fininha junto com arrepios e a loucura delirante da profanaçăo do corpo virgem. (RIOS, 1980, p. 64). 
O relato de Flávia da autopenetraçăo reforça o caráter solitário do erotismo, mas ao mesmo tempo deixa ainda mais explícito o desejo homoerótico da personagem como algo que parece estar enraizado nela. A figura da paixăo, representada pela vizinha, aliada à autossatisfaçăo materializam a identidade e o desejo da protagonista: uma lésbica que profana seu corpo virgem, em busca de prazer, de satisfaçăo sexual, que é alcançado ao pensar em outra mulher, outro corpo feminino.

\section{CONSIDERAÇÕES FINAIS}

Partindo da obra de Cassandra Rios, procuramos fazer uma leitura sobre as representaçôes da mulher lésbica, tendo como objetivo evidenciarmos questōes diversas relacionadas à identidade lésbica e ao homoerotismo feminino. É nas linhas e entrelinhas da escrita de Cassandra Rios, que durante muito tempo foi silenciada, que fomos capazes de refletir sobre alguns discursos enrijecidos e preconceituosos, que perduraram e ainda perduram ao longo do tempo, sobre a lesbianidade; sobre corpos e identidades considerados marginais e transgressores a partir de uma perspectiva heteronormativa que julga e subjuga corpos e sujeitos que escapam à norma.

Ao narrar o seu desejo por outra mulher, Flávia, nossa protagonista questionadora, perpassa por lugares e possibilidades censurados na década de 1980 e que até hoje parecem ser tabus, como, por exemplo, a representaçâo do erotismo entre corpos femininos; a satisfaçăo do toque e do prazer entre duas mulheres; além de uma ruptura com o ideal de mulher lésbica ao apresentar uma protagonista lésbica feminina; elementos que levam a protagonista a indagar sobre sua identidade, tentando compreender a si própria, seu corpo, seus desejos e o modo como a sociedade a vê.

Quando Michel Foucault (1979, p. 244) trata da sexualidade humana ele afirma que há um dispositivo, que pode ser compreendido como um "conjunto decididamente heterogêneo que engloba discursos, instituiçôes, organizaçōes arquitetônicas, decisóes regulamentares, leis, [...]", dentre outras coisas, que foram criadas para controlar e estabelecer verdades a serem seguidas pelo homem. Essa é uma das razóes pelas quais o homoerotismo é criticado, uma vez que o desejo entre pessoas do mesmo sexo "interfere" numa ordem pré-definida.

Dessa forma, de acordo com o autor, esse dispositivo acaba intervindo na subjetividade dos indivíduos. No entanto, Foucault (1979) contesta o caráter "absoluto" dessas afirmaçōes e introduz o discurso da libertaçâo sexual, que traz reflexóes significativas sobre a homossexualidade, as quais questionam, inclusive, a cultura falocêntrica, como ocorre, por exemplo, no romance de Cassandra Rios ao abordar o desejo homoerótico de Flávia por Kênia.

Na narrativa de Cassandra Rios, o enaltecimento do falo é inexistente por dois motivos: o primeiro é porque se trata do erotismo entre duas mulheres; e o segundo é porque esse desejo nasce a partir da imagem, da figura da mulher amada, isto é, de um conjunto estético e visual que desperta sensaçōes através da memória: "A sensualidade nasce com a vida, e no modo como eu olhava e admirava os pés de dona Kênia estava a primeira manifestaçăo da sexualidade. Cheguei a debruçar-me para cheirá-los com cuidado, pois tinha certeza de que eram perfumados" (RIOS, 1980, p. 03). 
Neste romance, o desejo de Flávia se constitui de maneira mais sensitiva, o que nos remete ao pioneirismo de Cassandra Rios na representaçăo das mulheres lésbicas, pois sua escrita, levando em consideraçăo o contexto histórico, já ia contra o constructo social a respeito da representaçăo da mulher lésbica ao romper com uma imagem estereotipada.

O discurso do senso comum de que a mulher lésbica deve desempenhar uma performance de masculinidade (mas de forma caricatural), é desfeito pela autora quando, por meio da personagem principal, ela critica este estereótipo, havendo uma representaçăo da mulher lésbica e de sua identidade a partir da feminilidade, o que nâo a faz menos lésbica em relaçăo àquelas que têm uma performance mais masculinizada, pois năo podemos compreender a identidade como sendo fixa.

Esta ruptura pode ser percebida através da descriçăo das características, primeiro de dona Kênia, a vizinha, "heterossexual", extremamente feminina, delicada, de pele suave e perfumada; depois, por meio da caracterizaçấo da protagonista Flávia, que adorava seus vestidos, cabelos longos e, sobretudo, que privilegiava sua feminilidade.

Acreditamos que a escolha narrativa de Cassandra Rios certamente foi imprescindível para combater, ou pelo menos para provocar, pensamentos conservadores da época, tendo em vista toda a estigmatizaçăo à qual os homossexuais, de forma geral, estavam (estăo) acometidos.

Contudo, consideramos de fundamental importância o questionamento em torno de um posicionamento, talvez, excludente e até preconceituoso nesta narrativa. Isto é, no romance, as lésbicas masculinizadas săo discriminadas até pela protagonista: "Metida a homem, andar de fanfarrăo, empostando a voz, sacudindo as pernas arreganhadas" (RIOS, 1980, p. 57).

Neste sentido, há, na narrativa, um questionamento sobre as diferentes performances das personagens lésbicas, que podem ser masculinizadas ou năo, justamente porque as performances podem variar de contexto para contexto e por que a identidade lésbica năo pode ser compreendida como algo fixo, rígido, que deve se encaixar em padrăo pré-estabelecido.

Portanto, o resgate da obra de Cassandra Rios nos permite afirmar que sua literatura nos consente questionar, rever, e repensar os estereótipos atribuídos às mulheres lésbicas, assim como compreender que a identidade lésbica é fluida. 


\section{REFERÊNCIAS}

AMORIM, Fabiana Eloi de. As concepçóes de conjugalidade e as convençóes de gênero e sexualidade de negra/o(s) homossexuais soteropolitana/o(s). 2014 . 72 fl. Monografia (graduaçăo) - Universidade Federal da Bahia. Faculdade de Filosofia e Ciências Humanas, Salvador, 2014.

BATAILLE, Georges. 0 erotismo. Traduçáo de Antonio Carlos Viana. Porto Alegre: L\&PM, 1987.

BEAUVOIR, Simone de. 0 segundo sexo: fatos e mitos. Traduçăo de Sérgio Milliet. 2. ed. Sáo Paulo: Difusáo Europeia do Livro, 1967.

BORILLO, Daniel. Homofobia: história e critica de um preconceito. Traduçâo de Guilherme Joăo de Freitas Teixeira. Belo Horizonte: Autêntica Editora, 2010.

BUTLER, Judith. Problemas de gênero: feminismo e subversivo. Traduçăo de Renato Aguiar. Rio de janeiro: Civilizaçăo Brasileira, 2003.

BRASIL. Decreto-lei n ${ }^{\circ}$ 93, de 21 de Dezembro de 1937. Cria o Instituto Nacional do Livro. Disponível em: http://www.planalto.gov.br/ccivil 03/Decreto-Lei/1937-1946/Del093. htm. Acesso em: 16 de Jan. de 2020.

BRASIL. Decreto-lei n 1.077, de 26 de Janeiro de 1970. Dispóe sobre a execuçâo do artigo 153, § 8 ${ }^{\circ}$ parte final, da Constituiçâo da República Federativa do Brasil. Disponível em: http://www.planalto.gov.br/ccivil_03/decreto-lei/1965-1988/Del1077.htm Acesso em: 16 de Jan. de 2020.

DIAS, Mariane Bovoloni. Jornalismo cultural e contestaçâo: uma análise do livro "Nicoleta Ninfeta", de Cassandra Rios. 2012. 77f. Trabalho de Conclusăo de Curso (Bacharelado em Jornalismo) - Graduaçâo em Comunicaçâo Social: Universidade Estadual Paulista, Bauru, 2012.

FOUCAULT, Michel. Microfísica do Poder. Organizaçăo e traduçăo de Roberto Machado. Rio de janeiro: Ediçōes Graal, 19179.

GARBIN, Raíssa Oliveira. Os livros e a censura durante o Regime Militar: uma análise a partir de três obras de destaque a respeito do tema. 2013. 44f. Trabalho de Conclusáo de Curso (Bacharelado em Biblioteconomia) - Graduaçăo em Ciência da Informaçâo: Universidade de Brasília, Brasília, 2013.

GUIMARÅES, Anderson Fontes Passos. "Uma lésbica é uma mulher?": vozes e silêncios. Dissertaçâo (Mestrado em Estudos Interdisciplinares sobre Mulheres, Gênero e Feminismo) - Mestrado em Filosofia e Ciências Humanas: Universidade Federal da Bahia, Faculdade de Filosofia e Ciências Humanas, Salvador, 2013.

NAVARRO-SWAIN, Tânia. 0 que é lesbianismo. Sáo Paulo: Brasiliense, 2004.

NÓBREGA, Isabela Silva. (I)Moralidade e Censura: prazeres desviantes e sexualidade na obra de Cassandra Rios (1968-1977). 2015. 215f. Dissertaçăo (Mestrado em História e Cultura Histórico) - Mestrado em História: Universidade Federal da Paraíba, Joâo Pessoa, 2015. 
PEREIRA, Ana Gabriela Pio. As disposiçóes da lesbianidade na ficçăo as Traças, de Cassandra Rios. 2013. 89 f. Dissertaçăo (Mestrado em Crítica Cultural) - Mestrado em Letras: Universidade do Estado da Bahia, Alagoinhas, 2013.

PIOVEZAN, Adriane. Amor romântico X deleite dos sentidos: Cassandra Rios e a Identidade Homoerótica Feminina na Literatura (1948-1972). 2005. 105f. Dissertaçâo (Mestrado em Estudos Literários) - Mestrado em Letras: Universidade Federal do Paraná, Curitiba, 2005.

RIOS, Cassandra. Eu sou uma lésbica [1980]. $1^{\text {a }}$ Ed. Lebooks Editora: 2019.

. Copacabana posto 6 - A madrasta. Rio de Janeiro, 1969.

Ariella, a paranóica. Săo Paulo: Discubra, 1969.

A serpente e a flor. Rio de Janeiro. Ed. Record. 1972.

. Veneno. Rio de Janeiro: Editora Record, 1968.

As traças. Rio de Janeiro: Record, 1981.

. Volúpia do Pecado. Sâo Paulo: A voz dos livros, 3a ed, 1955.

Macária. Rio de Janeiro: Hemus, 1973.

. Nicoleta Ninfeta. Rio de Janeiro: Record, 3 a ed,1973.

Marcella. Rio de Janeiro:Record, 1975.

A Breve Estória de Fábia. Editora Hermus, 1972.

A Borboleta Branca. Editora Gama, 1980.

SALIH, Sara. Judith Butler e a Teoria Queer. Traduçăo e notas de Guacira Lopes Louro. Belo Horizonte: Autêntica Editora, 2015.

VIEIRA, Kyara Maria de Almeida. “Onde estăo as respostas para as minhas perguntas"?: Cassandra Rios - a construçáo do nome e a vida escrita enquanto tragédia de folhetim (1955 - 2001). 2014. 234f. Tese (Doutorado em História do Norte-Nordeste do Brasil) - Doutorado em História: Universidade Federal de Pernambuco, CFCH. Programa de PósGraduaçâo em História, Recife-PE, 2014.

Recebido em 19/03/2020

Aceito em 01/07/2020 